International Journal of Linguistics, Literature and Culture
Available online at https://sloap.org/journals/index.php/ijllc/
Vol. 5, No. 6, November 2019, pages: 48 59
$\begin{aligned} & \text { ISSN: 2455-8028 } \\ & \text { https://doi.org/10.21744/ijllc.v5n6.763 }\end{aligned}$

\title{
Lexicon in Batar Text: Ecolinguistics View
}

Maria Magdalena Namok Nahak ${ }^{\text {a }}$ I Wayan Simpen ${ }^{\text {b }}$ Ida Bagus Putra Yadnya ${ }^{c}$ Ni Made Sri Satyawati ${ }^{d}$

Article history:

Received: 27 May 2019

Accepted: 31 July 2019

Published: 15 October 2019

Keywords:

Batar;

ecolinguistic;

ideology;

meaning;

text;

\section{Abstract}

This research aimed to describe the ideology and the meaning of lexicons used in the text of Batar that found in Mallaca society, East Nusa TenggaraIndonesia. The basic theory applied in this research was an Ecolinguistics theory with three logical dimensions (ideological, biological, and sociological). In addition, the cultural-linguistic theory was also applied. The approach used in the current research was qualitative descriptive. In collecting data, fieldwork methods were used. On the other hand, methods of participatory observation, interviews, and triangulation were also applied to obtain data. The results have shown that the ideologies laid behind the lexicon were ideologies of hope for rain, the ideology of successfulness in the process of planting, and the ideology of a hope that the harvest will be abundant. The meanings behind the use of the text were stylistic meanings, affective meanings, reflexive meanings, religious meanings, social meanings, and collective meanings.

2455-8028 ${ }^{\circ}$ Copyright 2019. The Author. This is an open-access article under the CC BY-SA license (https://creativecommons.org/licenses/by-sa/4.0/) All rights reserved.

\section{Author correspondence:}

Maria Magdalena Namok Nahak

Unimor, NTT, Indonesia.

Email address: marianahak@gmail.com

\section{Introduction}

Tetun is a local language in Timor Island, Indonesia. The language has lived and functioned in the various aspects of the life of Malacca community, East Nusa Tenggara- Indonesia. In addition, it is a means of communication, identity markers, and unifying its speakers. The language also becomes a pocket of local ethnic culture of Malacca. As a pocket of Malacca ethnic culture that has been passed down for generations, the Tetun language holds a wealth of ethnic culture. The richness of ethnic culture in Malacca is in the form of various kinds of knowledge and experience

a Unimor, NTT, Indonesia

b Universitas Udayana, Denpasar, Indonesia

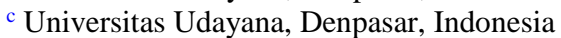

${ }^{\mathrm{d}}$ Universitas Udayana, Denpasar, Indonesia 
in speaking and managing their culture as well as utilizing the various natural resources in their environment. Everything is recorded, saved, inherited in Tetun language (Mbete, 2013).

Related to ecolinguistic studies, Santoso (2017), stated that society, language, and environment are inseparable. They are a trinity. In essence, as humans speak, they occupy a certain space and time. On the other hand, the language develops dynamically along with the development of the language community itself. Likewise, science continues to develop continuously, including language studies related to environmental factors. Seeing the various changes above, there have been various uses of language in various spheres of life, such as social, cultural, political, economic, public service advertisements, and so on. More specifically, the treasures and uses of the language can be seen in the text of batar. Batar is a local lexicon of Tetun Language which means 'corn'. It is, especially, referred to as corny or the activity of planting and harvesting corn.

It is important to realize that when the language of ecology is used rarely, the environment, undeniable, is going to be damaged. In contrast, when the environment is at a critical threshold, the environmental rescue movement is increasingly echoing everywhere, including the use of agricultural language, and the movement will save the environment. In this case, this descriptive study of agricultural lexicons of batar will save the environment in Mallaca.

The geographical and topographical condition of Malacca, which is mostly lowland, makes gardening/ agricultural activity as the only choice for the Malacca people to fulfill their daily needs. The Malacca community has a high dependency on land / cultivated gardens/ fields. It is also maintaining ancestral customs. This system, batar, is an inseparable part of the Malacca culture. This is reflected in the trust of the people of Malacca. As stated above, batar is the local language of Tetun which means 'corn'. Malacca, like Javanese and Balinese, recognizes the mythology of the origins of corn. 'Corn' or batar, in other regions, is recognized with the mythology of the origins of rice as the Goddess Sri (in the native language, it is called Dewi Sri), or in Flores- Indonesia, it is called Ine pare 'mother of rice'. Related to Dewi Sri and Ine Pare, Malacca community understand the term as 'to'os nain' as the king of the garden. The existence of this myth shows that the culture of gardening/ agriculture, in this case, the tradition of batar, is an old tradition.

In traditional societies, batar is manifested in ritual texts. Various rituals were performed in honoring to'os nain 'king of the garden'. The purpose of the ritual is to establish and to maintain a harmonious relationship with to'os nain as the king of the garden.

The period of planting batar is divided into the pre-planting, planting, harvesting, and post-planting periods. The pre-planting period consists of the period of land preparation until the land is ready to be used. The planting period starts from the planting stage of the batar, maintaining stage, until the stage of the development of planting the batar. The post-planting period is marked by the stage of harvesting the batar, picking the batar from its stem, and the stage of storing it in the traditional house (as a symbol of offering harvest to the ancestors). The use of language is inseparable from the richness of the lexicon that is compatible with the environment. If the environment is extinct, the use of the lexicon associated with the environment will also become extinct.

Likewise, the language in the text of traditional agricultural in Tetun Fehan. In the agricultural text of batar, there are ideologies which are very beneficial for everyone. Ideology itself is a process of digesting and living a variety of signs. Every sign has a meaning, and the meaning is the perception that strengthens into ideology. This was explicitly stated by Volosinov (1973). Without signs, there is no ideology. It is stated that since theoretically, there is no ideology without signs of verbs. In fact, Volosinov (1973), stated that the words are the most important ideological phenomenon (Volosinov, 1973). The concept of ideology, according to Storey (2018), contains five concepts as presented follows.

1) Ideology is institutionalization of systematic ideas that are articulated by a certain group of people.

2) Ideology is masking, deviation, or sounding a certain reality.

3) Ideology refers to ideological forms.

4) Ideology is a way since certain rituals and habits produce consequences that bind and attach people to the social order; the social order characterized by welfare gaps, status gaps, and increasingly prominent power gaps.

5) Ideology is the meaning displayed by text and practice, or which can be displayed by anything.

The five ideological concepts mentioned above contain a constellation or a combination of texts, ideas (which are institutionalized) and actions. This constellation makes the concept of ideology similar to the concept of culture

Nahak, M. M. N., Simpen, I. W., Yadnya, I. B. P., \& Satyawati, N. M. S. (2019). Lexicon in Batar text: Ecolinguistics view. International Journal of Linguistics, Literature and Culture, 5(6), 48-59. https://doi.org/10.21744/ijllc.v5n6.763 
(Volosinov, 1973). Storey (2018), stated that culture and ideology have got many similarities in their conceptual sphere.

In connection with linguistic research, ideology as a constellation between texts, ideas, and actions must be related to texts (everything that can be interpreted). Language, that is spoken to convey the meaning of the text, as well as actions as an expression of the meaning of the text is the mirror of ideology. Furthermore, ideology itself is something that constructs beliefs (Latupeirissa et al., 2019; Syufi et. al., 2019). Ideology is beliefs that are felt logical and reasonable by adherents. It is something that we believe in and thinks about. It is also said that language can influence as well as change ideology. It is something accepted (as fairness) so that it can influence the way of thinking of others (Latupeirissa et al., 2019). Thus, language is a vehicle to build, maintain and change and inherit ideology (Fairclough, 1996; Latupeirissa et al., 2019), because language is a place to store meaning and ideology together by members of a culture (Kovecses, 2006). Ideology as an order of ideas formed from a certain perspective. It is, thus, is a collaboration between perspective and perception which is certainly built by means of language.

\section{Materials and Methods}

Previous research that is significant and feasible related to the object of this study has ever conducted by Mbete $e t$ al., (2013). They conducted research about verbal as the representation of local knowledge, preservation function, and environmental preservation of Waijewa and Kodi Languages, in Southwest Sumba. From the results of this research, a study and interpretation, as well as the description of verbal treasures in the form of a lexicon in Waijewa and Kodi languages have been produced. It is found that the language contains rich and full of meaning and functions, namely: sociological functions, biological functions, and ideological function. As an environmental language, in a socio-ecological environment, the language represents cultivated biodiversity.

Another study that examines the lexicon's treasure as a part of this research has also be conducted by Koroh $e t$ al., (2017). She conducted research about the language and culture of Sabu-Raijua in Ecolinguistic perspectives. The similarities between Koroh's research and the current researchers are found the discussion. They are equally discussing language and culture with an ecolinguistic approach. They also applied the three-dimensions aspect described by Lindo \& Bundgaard (2000), namely ideological dimensions, sociological dimensions, and biological dimensions. The difference is that Koroh et al., (2017), talks about the language and culture of Sabu-Raijua's discourse while the current research describes the language and culture of Malacca.

Ecolinguistics itself is a discipline that examines the relationship between environment and language. It is an interdisciplinary linguistics study that combining ecology and linguistics (Mbete 2008). This scientific discipline examines the interrelationship between language and the human/social environment and the natural environment. The term ecolinguistics (language ecology) is related to the word 'ecology', which is the study of interactions between organisms and their environment and others.

In this context, the theory used is Ecolinguistic theory. It is an umbrella theory and is supported by other theories, namely: linguistic theory of text, culture, semantic, and theory of language change. On the nature of ecolinguistic studies, the concept of ecology should also be understood. Ecology is the study of functional relationships. Two parameters to be linked are language and environment.

Fill \& Muhlhausler (2006), stated that ecolinguistics is a general term for an approach that combines as well as studies languages and ecology (Lindo \& Bundsgaard, 2000). In addition, Steffensen (2007), stated that ecolinguistics is the study of the interrelation of biological, sociological, and ideological dimensions of language (Lindo \& Bunsdgaard, 2000) as well as the study of relation, interrelation, and extra-relation and their relationship with each other (Lindo \& Bundsgaard, 2000). They also argued that ecolinguistics regard to language as a whole, which included pragmatic, semantic, syntactic, morphological, phonetic, and other dimensions (Lindo \& Bundsgaard, 2000).

Ecolinguistics is a theory that links linguistics with ecology. Ecology in linguistics plays a very important role to understand the importance of ecology in linguistics views, especially for language survival. Departing from these philosophical thoughts, the environment becomes one of the important studies in linguistics. On the contrary, the facts have shown that an environment without language is dead. Without language, one cannot possibly reveal the secrecy of nature. Everything needs language. Through language, the community cannot be constructed. Knowledge and experience can only be expressed using language. After all, language is the result of the configuration of the human mind with its ecology that emphasizing itself as an ecological creature. 
Language illustrates how someone thinks about something that exists in the real world including culture and agriculture. The coding of each culture naturally experiences differences or varies. The form of coding can occur through lexicalize, grammaticalized, textualized, and cultural. Coding differences can be seen in the level of lexicon, grammatical, textual, and cultural wealth.

Ecolinguistic expert, Haugen (1975), described the natural environment of a language as the language user community. He stated that the language actually exists in the speaker's brain which only functions to connect speakers with others, and with the natural surroundings, namely the social environment and the natural environment. Furthermore, Haugen (1975); Fill \& Muhlhuasler (2006), stated that ecology can be distinguished psychologically and sociologically. Psychological, ecology interacts with other languages in the minds of bilingual and multilingual speakers. Sociological, ecology interacts with the society that functions as a medium of communication. The ecology of a language is discovered by people who learn it, use it, and pass it to others. The following is a table about the language environment that is important in ecolinguistics.

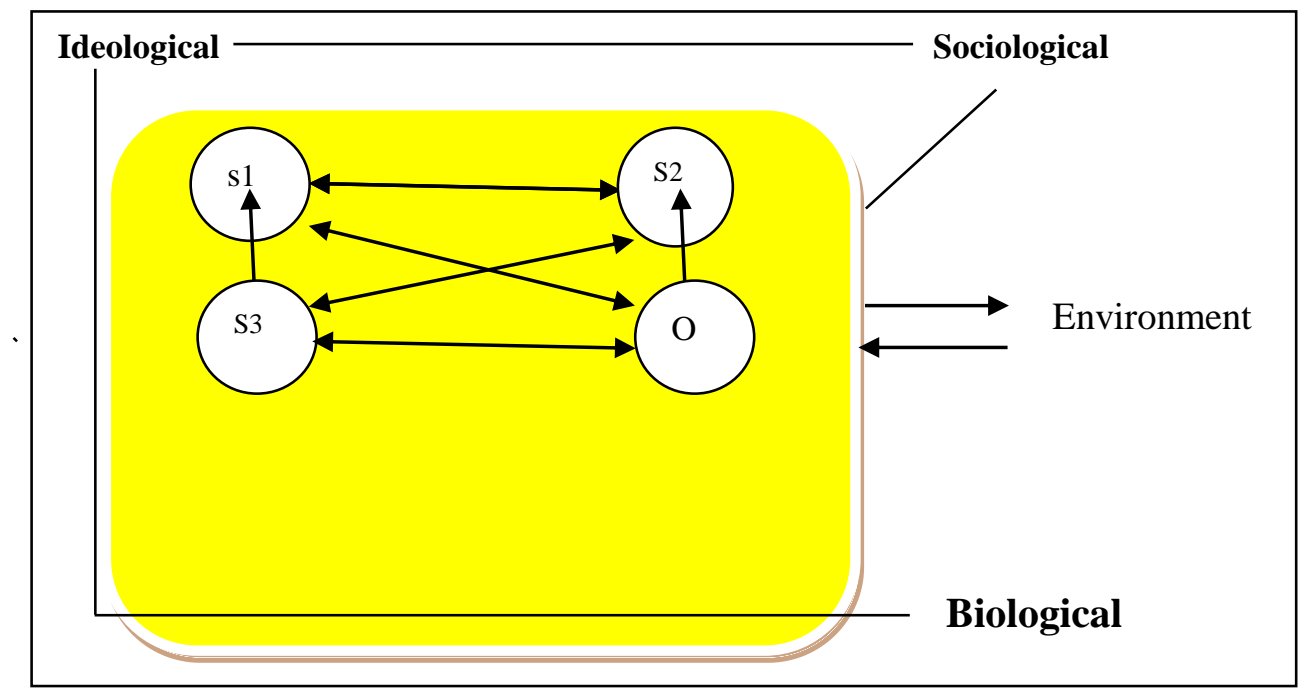

Figure 1. The relationship between Ideological, Sociological, and Biological Related to Language Changes

Note:

S1 : Text maker

S2 : Text consumer

S3 : Context

$\mathrm{O}$ : Objects referred in a communication

The above diagram shows that dialogue involves at least three people or subjects (Lindo \& Bundsgaard, 2000). In this context, even though only two people are involved in communication, there is actually always an anonymous third party involved in it. The three dimensions above are interconnected between one another. The ideological dimension is related to individual mentality, collective mentality, cognitive, ideological systems, and psychic systems, while the sociological dimension is related to the way humans manage their relationships with each other. The biological dimension is related to the biological collectivity of humans who live side by side with other species (animals, plants, land, sea, etc.). The phenomenon of language runs in a continuous and interrelated way Language is the object of these three dimensions (Lindo \& Bundsgaard, 2000).

This research is classified as a qualitative descriptive study. The use of a qualitative approach was supported by a simple quantitative approach. It was aimed to obtain facts and information about the ideo-socio-biological aspects of Tetun Fehan. This approach was chosen to get the treasures phenomena of lexicons, speech, and knowledge of the environment, in particular, an agricultural environment of batar. Next, this research was conducted in Malacca District, Timor, East Nusa Tenggara. The choice of Malacca Regency as the research location, besides related to research problems, it is also based on several considerations. The other considerations are: (1) the historical setting of

Nahak, M. M. N., Simpen, I. W., Yadnya, I. B. P., \& Satyawati, N. M. S. (2019). Lexicon in Batar text: Ecolinguistics view. International Journal of Linguistics, Literature and Culture, 5(6), 48-59. https://doi.org/10.21744/ijllc.v5n6.763 
Tetun Fehan, (2) the character of the agricultural environment, and (3) the strong character of the Tetun Fehan language.

The data of this research were traditional lingual units (lexicon) of batar farming activity texts were used for agricultural rituals in Malacca community. In qualitative research, the selected data was carried out by the researcher as the primary data. This type of data and research were a lexicon of batar text and field research as primary data. The data used in this research was oral data (which then transcripted) of text of batar informant in the Malacca society. Sources of data in this study were obtained from people who have special expertise and have a wealth of language (ecolexicons) in the speech community of the Malacca people. The informants were those who have got knowledge, understanding, and utilization of the batar agriculture activity in the speaking community of Malacca.

Data obtained directly from informants through interviews. In determining the informant, a snowball sampling technique was used. It is a technique with the help of key informants. Based on the criteria set, there were 25 (twenty-five) farmers (cultivators) who understand about batar who acted as key informants. Another informants selected were 15 (fifteen) older speakers (cultural) who have known well about the use of the textual lexicon in batar. In addition, ten (10) key informants were fukun 'elders' as the holders of traditional rituals of batar.

The method used by researchers in collecting data while in the field is the field linguistic method, namely (1) direct elicitation, (2) recording method, (3) elicitation checking method (Creswell \& Poth, 2017). In analyzing research data, researchers used the inductive method. Data analysis technique used in this study is a qualitative technique. After all data were collected, they were then processed or analyzed. This technique aims to make a systematic, factual and accurate description of the data and the relationships of the phenomena being studied. The results of the analysis of this study will be presented using formal and informal presentation methods (Sudaryanto, 1993). The formal method is a method that uses the linguistic symbol, while the informal method in its operation is a method of presenting data that uses words or sentences.

\section{Results and Discussions}

\subsection{Ideology in the Text of Batar}

People of Malacca, Timor, East Nusa Tenggara- Indonesia, has got a culture that is very closely related to a natural environment. It can be seen on each side of the lives of them in using or exploiting the natural environment, managing them as the means to fulfill daily need. Batar is one of the most important carbohydrate-producing crops in the world, besides wheat and rice. The community stated that Tetun Fehan has had the belief that from the corn (batar), Malacca people can live. Farming batar is believed as the only food for them. In addition, batar represents culture.

According to Lindo \& Bundsgaard (2000), the functions and meanings of ideology are linked to individual mental, effective mental, cognitive, ideological systems, and psychic systems. As also stated Thomson (2000), ideology presents and works through speech or language used. In this context of Tetun Fehan language, ideology and meaning contain in the speech of batar constructs mindset, ideas, and even the collective story of the language of Tetun Fehan in the cultural community. The function and hope contained in every utterance in the batar activity rituals are expressed during the planting, planting, post-harvesting, and harvesting. Following described the function and meaning of ideology which is expressed in the text of batar.

\subsection{Ideology and Meaning of Hope in Contextual Culture of Batar}

Agronomical and cultural context of batar in Tetun Fehan can be specified and described as follows.

\section{Ideology of Hope for Rain as a Source of Life}

Malacca people, generally, work as farmers. Their lives are very dependent on nature. The people have got a ritual tradition in each of their life activities. The unity of life of Malacca people has a close relationship between rites and agricultural myths, which is also closely related to traditional religious beliefs. The dependence of dryland farming is very high. However, without rain, which provides water to meet the biological needs of rice, corn, humans and other living things cannot live. The following is the text in Tetun Fehan language which contains the meaning of the same expectation as a traditional batar 'corn' farming activity. 
Data :

Ata oan hakmasin no halon
Servant child hope and beg
"Your servant hope and beg"

\section{Ba kukun no kroman raiklaran}

For dark and light earth

"The seen and unseen"

Iha leten no as ba.

in above and high there

"The Highest (God)"

Fini raikabun a amifo tonentian ne

Seed land stomach we give there already this

"The seed has already been planted"

\section{Matun udan learmai ami}

Come down rain heavy us

"May the rain flow down heavily"

The data snippet contains the expectations and requests for Tetun Fehan. In this case, farmers who plant farming in batar order to get rain as a source of water. The peasants likened themselves as 'the poor' and emahills 'the helpless' needed the mercy of others. Thus, interdependence farmers of batar is really concerned to livelihood in farming batar.

In relation to the water needs of the farmers, they monitor the season and have prepared everything to plant before the rainy season arrives so that the planting process is immediately carried out. To get this, batar farmers called themselves as poor and helpless people, therefore they ask mercy from the Creator, ancestors, and the owner of nature. The activity called 'Husu Udan Wen'.

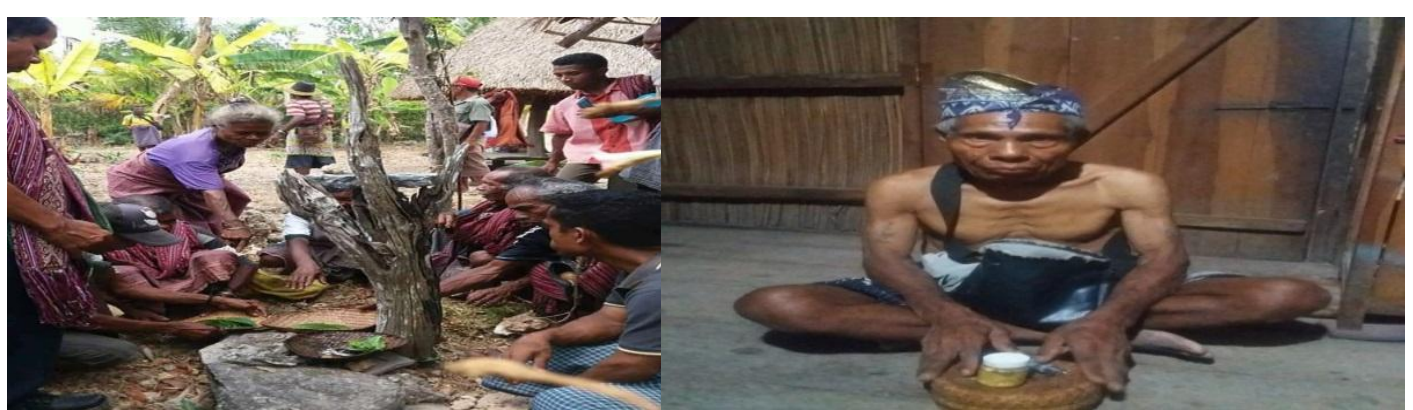

Figure 2. Husu udan wen 'asking for rain' Source: Documentation

The activity of husu udan wen 'asking for rain' is one of the important rituals related to rain. Rain in East Timor is rarely, so it is believed that the rain can be brought in according to human will (Foni, 2002). The ritual is the same as in the previous ritual. The cause is generally sought from the implementation of the previous ritual, whether there is a ritual error, or an error in other aspects, which causes disharmony between the human world with spirits and spirits (Foni, 2002). If the cause has been found, the perpetrators of the act can be corrected (Foni, 2002), and villagers must perform rituals in several places to eliminate the mistakes.

\section{The ideology of Expectation for Smoothness in the Planting Process}

After expecting rain, the semantic text of prayer also contains the meaning of hope. The meaning of the hope in question is that the planting process will run smoothly, as an initial stage for the growth of food plant the batar to

Nahak, M. M. N., Simpen, I. W., Yadnya, I. B. P., \& Satyawati, N. M. S. (2019). Lexicon in Batar text: Ecolinguistics view. International Journal of Linguistics, Literature and Culture, 5(6), 48-59. https://doi.org/10.21744/ijllc.v5n6.763 
flourish. It is called batar furi. Rituals of batar furi also performed by a fukun The fukun, in this ritual, will pray so there will no obstacles. They hope the process of planting will be conducted smoothly. After finishing the prayer, the community and the furi will be having meal together. Next, they will look for the appropriate time of planting batar.

The ideology of Hope that the harvesting of Batar will be Abundant

Data:

Malo no fulin no isin ba ami

Make article name of seed article name of seed go we

"Grow and bear fruit"

Oras ne'e ai a moris ti'an ne,

now this loaf that live already

"The plant has bear fruit"

ami hodi ba uma lulik sia onan

Tan to'os no i'sin, tua no wen

Because Farm has fruit laru (traditional drink) has water

"Since the plants have got fruits and the laru has got water

The speech data above contains an expression of hope that in terms of planting the 'corn' batter fini rai kabun moris tian 'seed is alive', and blended with matun udan 'rain'. It shows that the speech community of Tetun Fehan has a belief that by pleading to Nai Maromak 'Lord God', the prayer will keep them away from various plagues which hinder plant growth.

\subsection{The Meaning of Traditional Texts of Batar}

The way humans fulfill their needs for food is not just adjusting to nature, but also by managing nature (cultívate) (Kusumohamidjojo, 2010). In relation to the meaning of a text, especially in the battar, according to Leech (2014), the meaning of a language can be analyzed includes stylistic meaning, affective meaning, and collocative meaning. The description of those three kinds of meaning is presented as follows.

\section{Stylistic Meaning}

In relation to the meaning to convey something, it can be seen from the monologue and also dialogue. In the lexicons of Tetun Fehan, the meaning of stylistic is related to geographical location and origin of the social environment. It can be seen in the following data.

Data:

foho sasaen rai fatuk

Mounth hill land rock

"The universe"

fhosi foho leten to'o rai henek

KONJ up head to wave break

'From the top of the mountain to the beach'

hose tasi lidun to'o tasi lidun

KONJ end sea to end sea

From the end of the sea to the other side of the sea'

mai ita hamulak

come us pray

'let us pray' 
The data clearly shows the geographical location in the Tetun Fehan neighborhood, which consists of very high mountains and very far between one village to other villages. People have to travel far to do an activity. In connection with medicine, one of the roads that is requested to give blessing is to ask for the blessing of the guardian of the universe. In this case, the speech community of Tetun Fehan has got a belief about the guardian of nature. They laid themselves to the natural environment.

The stylistic meaning in the batar text of the Tetun Fehan speech that is related to the discourse consists of the delivery delivered verbally and nomologically. Monologues that are delivered generally use special languages or special prayers that should not be heard by others.

The relatively temporary stylistic meaning in the text of batar can be delivered politely, by asking, rudely, and colloquial words, as well as confirming or ordering. The use of polite words and requests made for the process of pre-planting, planting, harvesting, and postharvest rituals. It is seen from the following data.

Data:

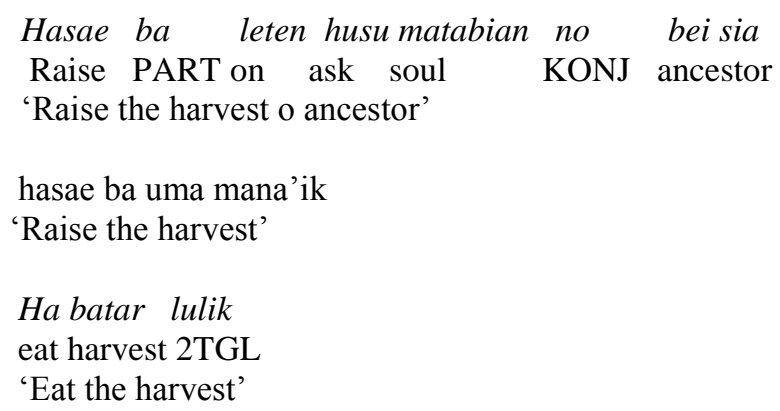

The data above shows the anger of the fukun 'the elder' against something more important than worldly problems or enmity with the occult creator.

\section{Affective Meanings}

Affective meaning is the meaning of the language that is seen as a reflection of the speaker's personal feelings towards people who listen to what is said or prayed for. This is a reflection of the feelings experienced by a fukun, namely 'maknakakaluk no Makaerkakaluk'. Feelings that arise can be positive or negative. The word manu uat los 'good', neon diak 'he is good' and langa 'lift' raise positive affective meanings, while ndate 'heavy', uat kleuk 'not straight' show negative affective meaning.

The affective meaning of the lexicon that appears in the hamis batar ritual contains a positive meaning. This can attract the attention of the kakaluk 'fetish holder'. The kakaluk is brave to pray and hope to win in order to overcome suffering. Lexicon hadiak 'restore' hasae bu at 'evil spirits' can give hope to someone, that s/he can be restored. Speech community of Tetun Fehan believe that the words spoken by mak kaer kakaluk/fukun 'elders' have had energy or strength. This is believed since when batar text is spoken, a mak kaer kakaluk 'customary holder/ elders' requested the help of Nai Maromak 'Almighty God' through the intercession of the matabian 'ancestors', and also rainain 'natural ruler' who rules the universe. It is seen in the following data.

Data:

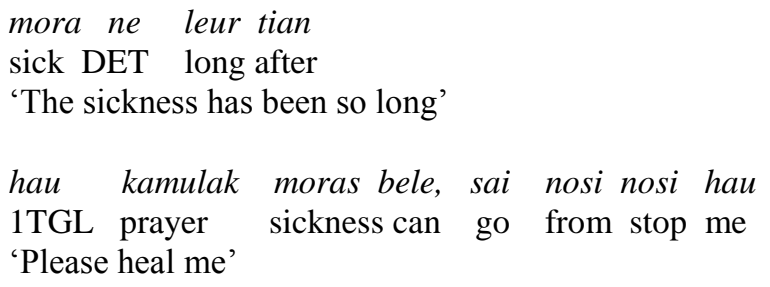

\section{Reflective Meaning}

Reflective meaning is the meaning that arises in terms of multiple conceptual meanings (synonymy). Speech community of Tetun Fehan has had a religion related to the healing / recovery process. In every prayer that is

Nahak, M. M. N., Simpen, I. W., Yadnya, I. B. P., \& Satyawati, N. M. S. (2019). Lexicon in Batar text: Ecolinguistics view. International Journal of Linguistics, Literature and Culture, 5(6), 48-59. 
expressed by someone, there is always a prayer expression to ask for miracle of healing and restoration. Since the community, majority, is a Catholic people, the prayer in Batar rituals are also related to Catholic teaching. Based on the teaching, prayer is also a kind of doing self-reflection. The speech community of Tetun Fehan, in conducting praying, do reflection weather themselves are in accordance with God or not. This kind of meaning, furthermore, drives to the next meaning which is called religious meaning.

\section{Religious Meaning}

Religious meaning is something abstract and is an important element in a culture. The meaning refers to what someone may do or not. This system regulates human relations with God, human relation to each other, and between humans and their environment. The whole system is imbued in an atmosphere that is felt as an atmosphere of kinship by the people who embrace it (Koentjaraningrat et al., 1970).

With the spirit of spirituality, humans express themselves and their lives to be formed in accordance with the spirit of the Creator. This is clearly found in the collective social life of Tetun Fehan and also the general public in other regions. The meaning of respect for the highest form, is a very important thing, which cannot be separated from humans and the natural. The meaning of surrender and request to always be protected is shown in the following data.

Data:

Maromak maak fo beran
Lord God KONJ give power
'Lord God who give us power'

Halo moras diak

Make sickness recover

'Please recover'

The fragmentary data of the ritual shows respect and a request from the Creator to keep the entire community from north to south, from the sickness / illness that is abundant in the local community. Speech community of Tetun Fehan has had a belief that by requesting the Almighty 'Nai Maromak' would certainly be granted.

\section{Social Meaning}

Speech community of Tetun Fehan as a social creature, like other speeches, has a sense of togetherness and humanism. The batar text 'corn' expresses the vertical relationship between humans and ancestors and supernatural powers. This happens because there is a harmonious relationship in the ritual ritual hasae batar fohon/atau hamis batar which is experienced by 'elders'. Society as a social creature is contained in the parameters of interaction, interrelation, and also interdependence between one community and another, and also related to the environment. Relationships revealed in speech between died ancestors and alive people become pillars of social meaning that have the strength that helped to strengthen the humanist and collegial point of view. A piece of batar text data can be seen as follows.

Data:

mai ita lifuan ida

come 1TGL voice one heart

'come and become one'

The data shows the social meaning seen in the sentence mai lifuan ida 'come and become one'. The phrase lia fuan $i d a$ indicates the presence of a power. In addition, there is a unification of power with the ancestors and also fellow to establish a sense of brotherhood in the restoration of maha kakaluk.

\section{Collective Meaning}

A meaning consisting of associations obtained in a tend to appear in the same environment. For example machetes, chisels, saws are words that appear in the carpenter (Chaer, 1994). The collocative meaning of the 'corn' batar text is 
adjusted to the situation and condition or place where the person is located. The following text illustrates associations about supernatural beings or those related to animals, such as the beliefs of local people.

Data:

$\begin{array}{llll}\text { La bele lao ba oras loromonu } \\ \text { Don't walk KONJ } & \text { day } & \text { sun } & \text { down }\end{array}$

'Do not walk in the dusk'

La bele lau kalan bot'

Don't can walk night big

'Do not walk in the mid-night'

Manu semo kalan iha ai leten

Chicken fly night loaf at up

'The chicken has jumped to the tree'

Fetofoiwai la bele tuur iha uma oin

Young Girl no may sit in house front

'Young girl do not sit infront of the house'

The data shows that loro monu 'dusk' and ai leten 'in the trees' are part of the shadow of supernatural beings. These words are associated with buiotuk 'masked man' who functions to frighten people of Mallaca. The meaning of the association implies that 'the traditional leader' must always be vigilant because it is not only a disease that attacks plants but a force in nature, especially supernatural beings, can also be the cause.

\section{Conclusion}

Based on the results of research and discussion about the ideology and meaning of lexicons in the batar text reveals the following. First, the ideology of hope for rain (Halon Udan). The peasants likened themselves as ata oan 'the poor' and ema kmukit 'hopeless people' who needed the mercy of others. Batar 'corn' is the basic needs of the community. Thus, the interdependence of corn farmers actually depends their lives on the cultivation of batar cultivation so that the harvest can be enjoyed. The ritual is one of the important rituals related to rain. Rain in East Timor is rarely, so it is believed that with the ritual, rain can be brought in according to the human will (Foni, 2002). Second, the ideology of successfulness in the planting process. The fukun prayed that the inhabitants of the unseen world do not disturb them while conducting agriculture activity in the garden. The aim is that farmers who gardened at the location would be avoided from danger, disaster, or disease. Third, the ideology of a hope that the harvest (batar) will be abundant. Finally, it is found that the meanings behind the use of the text are stylistic meanings, affective meanings, reflexive meanings, religious meanings, social meanings, and collective meanings.

\section{Conflict of interest statement}

The authors declared that they have no competing interest.

Statement of authorship

The authors have a responsibility for the conception and design of the study. We have approved the final article.

Acknowledgments

This work was supported by the Research Fund provided by LPDP, Indonesia

Nahak, M. M. N., Simpen, I. W., Yadnya, I. B. P., \& Satyawati, N. M. S. (2019). Lexicon in Batar text: Ecolinguistics view. International Journal of Linguistics, Literature and Culture, 5(6), 48-59. 


\section{References}

Chaer, A. (1994). Linguistik umum. Jakarta,, Indonesia: Rineka Cipta.

Creswell, J. W., \& Poth, C. N. (2017). Qualitative inquiry and research design: Choosing among five approaches. Sage publications.

Fairclough, N. (1996). A reply to Henry Widdowson's' Discourse analysis: a critical view'. Language and literature, 5(1), 49-56. https://doi.org/10.1177\%2F096394709600500105

Fill, A., \& Muhlhausler, P. (Eds.). (2006). Ecolinguistics reader: Language, ecology and environment. A\&C Black.

Foni, W. (2002). Ritus Agama Suku Atoni Pah Meto dalam Kegiatan Pertanian Lahan Kering, Studi di Kevetoran Tunbaba Kabupaten Timot Tengah Utara, Nusa Tenggara Timur.

Haugen, E. (1975). Pronominal address in Icelandic: from you-two to you-all. Language in society, 4(3), 323-339. https://doi.org/10.1017/S0047404500006709

Koentjaraningrat, R. M. (1970). Manusia dan kebudajaan di Indonesia. Djambatan.

Koroh, L. I. D., Mbete, A. M., Simpen, I. W., \& Yadnya, I. B. P. (2017). Perception of Sabu Raijua speech community about due (palm tree). International journal of linguistics, literature and culture, 3(4), 7-16.

Kovecses, Z. (2006). Language, mind, and culture: A practical introduction. Oxford University Press.

Kusumohamidjojo, B. (2010). Sejarah filsafat tiongkok: sebuah pengantar komprehensif. Jalasutra.

Latupeirissa, D. S., Laksana, I. K. D., Artawa, K., \& Sosiowati, I. G. A. G. (2019). On Political Language Ideology: Critical View of Indonesian President Speech. Journal of Language Teaching and Research, 10(4), 843-850. http://dx.doi.org/10.17507/jltr.1004.23

Leech, G. N. (2014). Meaning and the English verb. Routledge.

Lindø, A. V., \& Bundsgaard, J. (2000). Dialectical Ecolinguistics Three Essays for the Symposium 30 Years of Language and Ecology in Graz December 2000. Odense: University of Odense.

Mbete, A. M. (2008). Ekolinguistik: Perspektif kelinguistikan yang prospektif. Bahan Matrikulasi Program Magister dan Doktor Linguistik Program Pascasarjana Universitas Udayana.

Mbete, A. M. (2013). Penuntun Singkat Penulisan Proposal Penelitian Ekolinguistik. Denpasar: Penerbit Vidia.

Mbete, B., Nougier, M., \& Bridge, J. (2013). HIV, harm reduction and drug policy in Kenya.

Santoso, U. (2017). Hukum Agraria: Kajian Komprehenshif. Prenada Media.

Steffensen, S. V. (2007). Language, ecology and society: An introduction to dialectical linguistics. In Language, Ecology and Society (pp. 3-31). Bloomsbury Academic.

Storey, J. (2018). Cultural theory and popular culture: An introduction. Routledge.

Sudaryanto. (1993). Metode dan aneka teknik analisis bahasa: pengantar penelitian wahana kebudayaan secara linguistis. Duta Wacana University Press.

Syufi, Y., Budiarsa, M., Simpen, I. W., \& Satyawati, M. S. (2019). Correlation of irires noun towards sago: An ecolinguistic study. International Journal of Linguistics, Literature and Culture, 5(4), 25-33. https://doi.org/10.21744/ijllc.v5n4.696

Thomson, S. (2000). The Social Democratic Dilemma: Ideology, Governance and Globalization. Springer.

Voloshinov, V. N., Matejka, L., \& Titunik, I. R. (1973). Marxism and the Philosophy of Language [by] VN Volosinov. Translated by Ladislav Matejka and IR Titunik. 


\section{Biography of Authors}

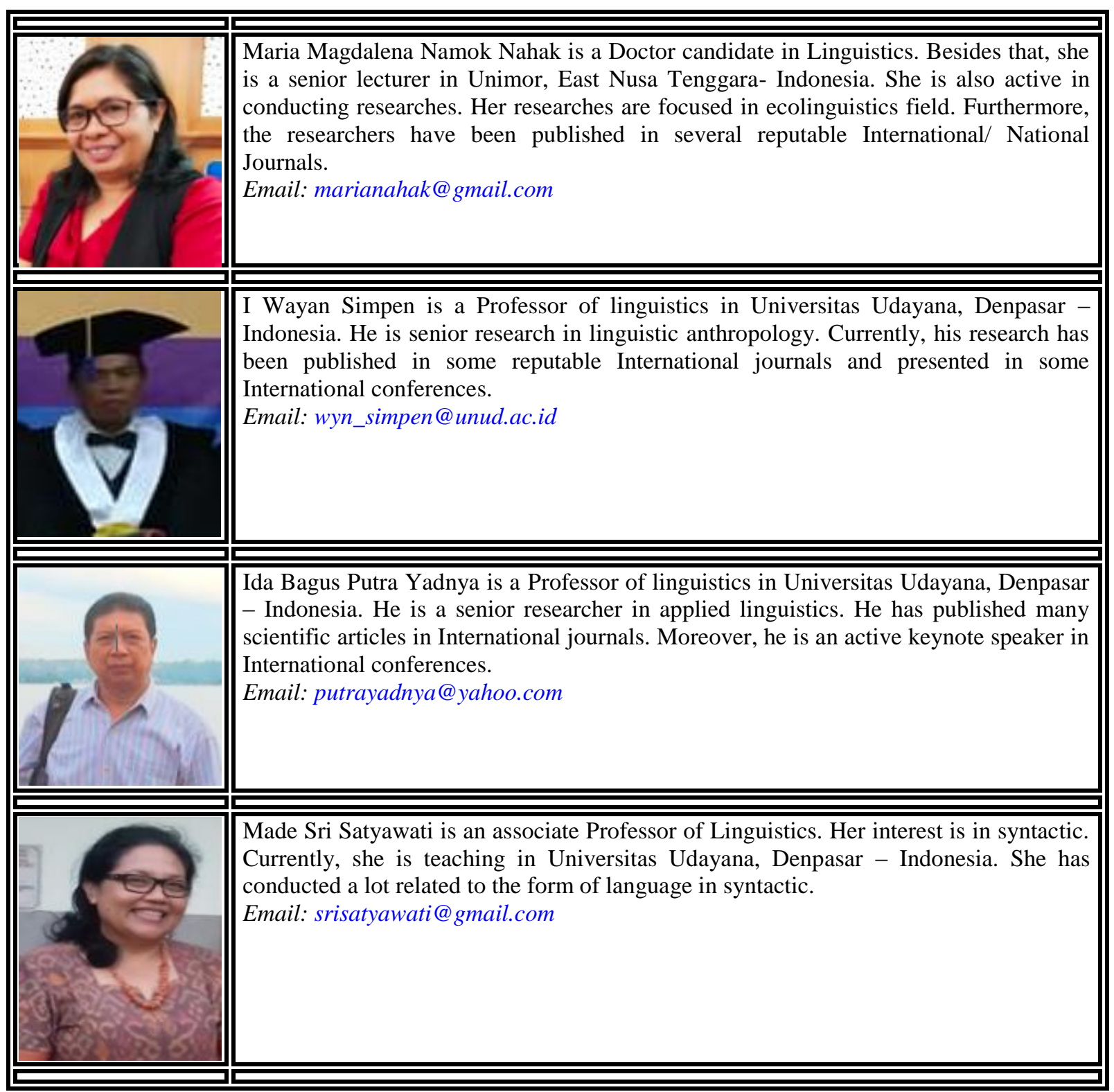

Nahak, M. M. N., Simpen, I. W., Yadnya, I. B. P., \& Satyawati, N. M. S. (2019). Lexicon in Batar text: Ecolinguistics view. International Journal of Linguistics, Literature and Culture, 5(6), 48-59. https://doi.org/10.21744/ijllc.v5n6.763 